\title{
Linking adaptive capability, product innovation and marketing performance: Results from Indo- nesian SMEs
}

\author{
Gunarso Wiwoho $^{a^{*}}$, Agus Suroso ${ }^{\mathrm{b}}$ and Siti Zulaikha Wulandaric
}

${ }^{a}$ PhD Student at Faculty of Economics and Business, Jenderal Soedirman University, Indonesia. Lecture at Putra Bangsa Economics College, Kebumen, Indonesia

${ }^{b}$ Professor at Faculty of Economics and Business, Jenderal Soedirman University, Indonesia

${ }^{c}$ Lecturer at Faculty of Economics and Business, Jenderal Soedirman University, Indonesia

\section{H R O N I C L E}

Article history:
Received: December 28, 2019
Received in revised format:
January 302020
Accepted: February 26, 2020
Available online:
February 26, 2020
Keywords:
Product innovation
Adaptability
Competitive advantage
Marketing performance

\section{A B S T R A C T}

The research aims to empirically verify the role of adaptive capability in its contribution to marketing performance, with product innovation as a mediating variable. This research was conducted in small and medium enterprises (SMEs) located in Central Java, Indonesia. A number of 253 questionnaires were distributed and adequately filled. Statistical analysis was conducted by using structural equation modeling with Smart-Partial Least Squares (PLS). The results show that the adaptive capability was positively related to product innovation, but not significant to marketing performance. Furthermore, our findings show that product innovation had a significant effect on marketing performance and it fully mediated the relationship between adaptive capability and marketing performance. These findings offer implications regarding how adaptive capability enhance marketing performance through product innovation in SMEs.

\section{Introduction}

In the growing of studies on marketing performance in small medium-sized enterprises (SMEs), numerous studies have revealed that the marketing performance of SMEs could be affected by the external environment in which they operate (Zahra, 1996). Bruce (2000) stated that a company's external environment can be used as a reference for evaluating marketing performance. Every top manager needs to understand the dynamic of the environment, and then formulate it into an appropriate strategy to benefit the entire organization. A good understanding of the environment will have an impact on the quality of innovation and marketing performance (Singh et al., 2017). Addressing this issue, in this case, adaptative capability plays an important role to improve marketing performance (Beal, 2000; Covin \&amp; Slevin, 1989; Keats \&amp; Hitts, 1998). Previous literature stated that a firm with high adaptive capability and have flexibility with their environment is able to achieve better performance (Zhu, Su, \& Shou, 2017; Talaja, 2013). Although the literature presents many studies that investigated this area, most analyses have been conducted in large corporations (Prajogo, 2016). Only a few studies have analyzed the relationship between adaptive capability and marketing performance in SME's perspective. Accordingly, this paper has several contributions. First, we explain the relationship between adaptive capability and marketing performance in Indonesian SMEs. Adaptive capability helps small firm interact with external entities such as costumer, technology, competitor, and also helps own-manager reshape internal strategy such as change management and resiliency (Ali, Sun \& Ali, 2017). Based on BPSStatistics (Bureau of Statistics) Indonesia report, in 2018, SMEs account $98.8 \%$ of all private sector companies, contribute 
$60.3 \%$ to Gross Domestic Bruto and employ $96 \%$ of the total workforce (BPS, 2018). Based on data from the Global Entrepreneurship Index in 2018, it is known that the growth in the number of SMEs in Indonesia has increased by as much as $4.4 \%$. On the other hand, SMEs always have constraints to survive and face tight competition in the global economy. The most prominent constraints are limiter resources (financial), lack of employee skill and creativity of owner-manager (Dirgiatmo et al., 2019). Therefore, it is important to investigate the extent to which the affiliation of adaptive capability and marketing perform in SMEs. Second, we propose product innovation as a mediating variable between adaptive capabilityand marketing performance. Ali et al. (2017) revealed that adaptive capability gives support for product innovation. The internal mechanism about how the business comprehends, what happens in the external business environment, and how this data is utilized trough adaptive strategy fostering knowledge required for creativity (Akgün et al., 2012). Accordingly, this study investigates the relationship between adaptive capability and marketing performance, as well as the mediating role of product innovation in this relationship.

\section{Theoritical Framework}

\subsection{Adaptive Capability and Marketing Performance}

The current business environment is characterized by rapid changes in customer preferences, technology, and competition. Companies must be more creative to sustain their survival efforts. Innovative ability, organizational learning, market orientation, and entrepreneurial ability become the main ability for an organization to achieve profit competitiveness (Hult \& Ketchen, 2001; Hurley \& Hult, 1999). The internal environment is connected to all organizational conditions including resources, abilities, and core competencies (Hitt et al., 2001). Meanwhile, the external environment is connected with the general environment, industry and competitive environment. Results from previous studies indicate that the environment can influence organizational performance (Bain, 1956; Hansen \& Wernerfelt, 1989). Marketing performance is the organization's ability to transform itself in the face of challenges from a long-term environmental perspective (Keats \& Hitt., 1988). Performance measurement is part of the organization's efforts to see the application of fitness strategies to deal with environmental changes. Living environment has become an important part of an organization and is imitated imperfectly. The organization needs to know its environment, and then manage it in an appropriate way to benefit the entire organization. A good understanding of the environment will have an impact on the quality of strategy and marketing performance. A dynamic environment illustrates the level of market and turbulence that is constantly unstable. Dynamic environments are caused by interconnections or relationships between organizations (Aldrich, 1979). The dynamic environment is operationalized as the latest product innovation that shows the main influence of performance measurement (Hambrick, 1983). Keats and Hitt (1988) state that dynamic environments are significantly related to organizational performance. Based on the statements that have been explained, the first hypothesis in this study is:

$\mathrm{H}_{1}$ : Adaptability Ability has a positive effect on Marketing Performance.

\subsection{Adaptive Capability and Product Innovation}

Adaptive is defined as firm's ability to identify and capitalize on emerging market opportunities (Hooley et al., 1992). Tuominen et al. (2004) revealed opportunity from external factors such as technological aspects, external market aspects, and internal organizational aspects. The most important aspect of adaptive capabilities is the ability to respond to external product market opportunities, the investment in marketing activities, and the speed of response to changing market conditions (Chakravarthy, 1982). Furthermore, previous research suggested that adaptability should lead to improve performance and innovation (Grinstein's, 2008). The second hypothesis of the present study is developed:

$\mathrm{H}_{2}$ : Product innovation has a positive effect on marketing performance.

\subsection{Product Innovation and Marketing Performance}

According to Geenhuizen and Indarti (2005), besides product and process innovation there are four types of innovation in SMEs. The four types of innovation are service, market, logistics, and organizational innovation. Innovation can occur simultaneously. For example, product innovation may require new techniques in the production process or innovation. New products, product innovations are needed to meet the needs of new markets, which states that new product excellence is very important in a competitive global market environment. These advantages are related to product development innovations that will produce market advantages and will ultimately win the competition. Geenhuizen and Indarti (2005) found that product innovation is the most important innovation, such as new product designs, and types of new products. Other important innovations are market and logistical innovations. The fact that creativity has an important influence on marketing performance, because it will provide benefits to develop the desired product for customers who like high creativity and unique products. Han et al. (1998) and Ismail (2015) state that marketing performance is influenced by environmental factors, innovation products, and market orientation that have a positive impact on marketing performance. Product innovation shows the introduction, development, and success of new products in the market. Product innovation can be in the form of changes in design, product components, and architecture. Product innovation is a potential thing to create thoughts and imaginations that will ultimately create customer loyalty. Product innovation is an important way for organizations to be able to adapt to 
changing markets, technology and competition. Based on the explanation that has been explained, the third hypothesis in this study is:

$\mathrm{H}_{3}$ : Product innovation has a positive effect on marketing performance.

\subsection{Mediating Role of Product Innovation}

Adaptive marketing capabilities are based on marketing activities and speed to respond to product or market opportunities (Oktemgil and Greenley, 1997). Adaptive capability will have a significant impact on the company's marketing performance if the adaptation process is carried out with the speed of responding to opportunities to develop or pass product innovation (Akgun, Keskin \& Byrne, 2012). Market adaptation in SMEs will have a significant impact on marketing performance if mediated by innovation, which means that SME marketing performance is highly dependent on the level of corporate innovation (Pardi et al., 2014). Altuntas et al. (2013) revealed that innovation is affected by market adaptation and it plays a mediating role to drive organizational performance. So, the fourth hypothesis in this study is:

$\mathrm{H}_{4}$ : Product innovation significantly mediates the relationship between adaptive capability and marketing performance.

\section{Methodology}

The population in this study were own managers in creative industry SMEs, which is located in Central Java, Indonesia. This survey conducted approximately 6 months during May-October 2019. A number of 380 questionnaires were distributed, 253 were completed and adequately filled. Thus, the usable response for this study is $66,57 \%$. Data were analyzed using structural equation modeling with Smart-Partial Least Squares (PLS).

\section{Results}

The results reveal that all minimum requirements are fit with the measurement model, as illustrated in Table 1. First, this study used a cut-off value of 0.70 significance for the loading factor $(\mathrm{p}<0.05)$. Loading of all items are above 0.70 . Higher levels of outside loading factors indicate a higher level of indicator reliability (Hair, Hollingsworth, Randolph, \& Chong, 2017). Second, all extracted mean values (AVE) exceed the 0.50 threshold, supporting the convergent validity of the construct steps. According to Table 2 and Fig. 1., discriminant validity shows the extent to which the construct is completely different from other constructs based on empirical standards (Hair, et al., 2014). Using Fornell-Larcker Criterion, it proved that the square root of each construct's AVE should have a greater value than the correlations with other latent constructs.

Table 1

Measurement Model Evaluation Result

\begin{tabular}{|c|c|c|c|c|c|c|}
\hline Variables & & Item & $\begin{array}{c}\text { Factor } \\
\text { Loadings }\end{array}$ & $\mathrm{CR}$ & AVE & $\begin{array}{c}\text { Cronbach } \\
\text { Alfa }\end{array}$ \\
\hline \multirow[t]{3}{*}{$\begin{array}{l}\text { Adaptive } \\
\text { Capability } \\
\text { (Lu et al., 2010) }\end{array}$} & $\mathrm{AC1}$ & $\begin{array}{l}\text { Meet a customer's demand changes } \\
\text { in terms of product and service } \\
\text { specifications }\end{array}$ & 0.842 & \multirow[t]{3}{*}{0,923} & \multirow[t]{3}{*}{0,923} & \multirow[t]{3}{*}{0,895} \\
\hline & $\mathrm{AC} 2$ & $\begin{array}{l}\text { Tailor products and services } \\
\text { according to a customer's request }\end{array}$ & 0.832 & & & \\
\hline & AC3 & $\begin{array}{l}\text { Respond quickly to the demand for a } \\
\text { product price change from a } \\
\text { customer }\end{array}$ & 0.799 & & & \\
\hline \multirow{5}{*}{$\begin{array}{l}\text { Product } \\
\text { innovation } \\
\text { (Jajja et al., } \\
\text { 2017) }\end{array}$} & PI1 & $\begin{array}{l}\text { Level of newness and uniqueness of } \\
\text { our products }\end{array}$ & 0.798 & \multirow[t]{5}{*}{0,905} & \multirow[t]{5}{*}{0,905} & \multirow[t]{5}{*}{0,861} \\
\hline & PI2 & $\begin{array}{l}\text { Customer orientation of our new } \\
\text { products }\end{array}$ & 0.844 & & & \\
\hline & PI3 & $\begin{array}{l}\text { Our frequency of introduction of } \\
\text { new products }\end{array}$ & 0.878 & & & \\
\hline & PI4 & $\begin{array}{l}\text { Contribution of our products in } \\
\text { expanding the market size }\end{array}$ & 0.839 & & & \\
\hline & PI5 & Value for customers in our products & 0.874 & & & \\
\hline \multirow{4}{*}{$\begin{array}{l}\text { Marketing } \\
\text { Performance } \\
\text { (Nuryakin \& } \\
\text { Ardyan, 2018) }\end{array}$} & MP1 & Sales growth & 0.816 & \multirow[t]{4}{*}{0,864} & \multirow[t]{4}{*}{0,864} & \multirow[t]{4}{*}{0,765} \\
\hline & MP2 & Increasing of products offering & 0.898 & & & \\
\hline & MP3 & Increasing of products values & 0.882 & & & \\
\hline & MP4 & Market coverage & 0.723 & & & \\
\hline
\end{tabular}


Table 2

Discriminant Validity Using Fornell-Larcker Criterion

\begin{tabular}{lccc}
\hline & Adaptive Capability & Marketing Performance & Product Innovation \\
\hline Adaptive Capability & $\mathbf{0 . 8 2 4}$ & & \\
Marketing Performance & 0.579 & $\mathbf{0 . 8 4 0}$ & $\mathbf{0 . 8 4 1}$ \\
Product Innovation & 0.634 & 0.790 & $\mathbf{0}$ \\
\hline
\end{tabular}

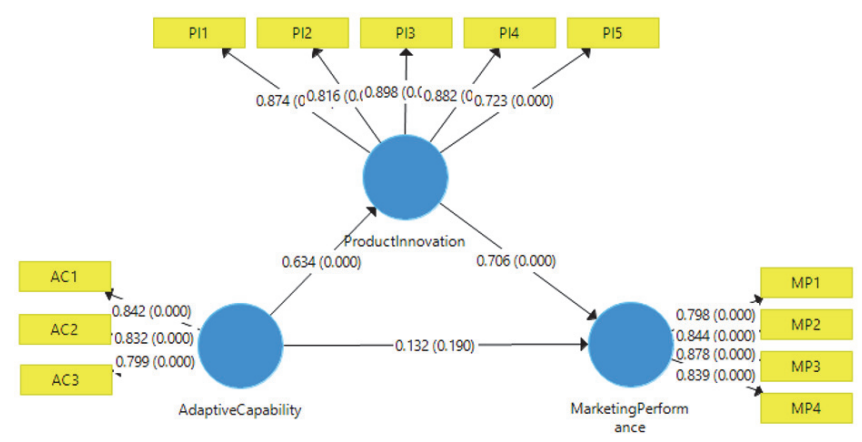

Fig. 1. The results of SEM implementation

\subsection{Structural Model}

Table 3

Summary of Hypothesis Assessment

\begin{tabular}{|c|c|c|c|c|c|}
\hline Direct & $\begin{array}{l}\text { Original } \\
\text { Sample }\end{array}$ & $\begin{array}{l}\text { Standard } \\
\text { Deviation }\end{array}$ & T- Statistics & P-Values & Hypotheses testing results \\
\hline Adaptive Capability $->$ Marketing Performance & 0,132 & 0,100 & 1,313 & 0,190 & H1: Rejected \\
\hline Adaptive Capability -> Product Innovation & 0,634 & 0,070 & 9,107 & 0,000 & H2: Supported \\
\hline Product Innovation -> Marketing Performance & 0,706 & 0,098 & 7,231 & 0,000 & H3: Supported \\
\hline \multicolumn{6}{|l|}{ Spesific Indirect Effect: } \\
\hline $\begin{array}{l}\text { Adaptive Capability -> Product Innovation -> } \\
\text { Marketing Performance }\end{array}$ & 0,448 & 0,085 & 5,235 & 0,000 & H4: Supported \\
\hline
\end{tabular}

Table 3 summarizes the results of the best-fit model and explains the direct relationship between adaptive capability and marketing performance with product innovation as mediating variable. The test results show that Adaptive capability has no significant relationship with marketing performance. Surprisingly, the first hypothesis $\left(\mathrm{H}_{1}\right)$ of this study is rejected $(\mathrm{p}>0.05)$. Further results show that adaptive capability has a significant effect on product innovation. Still, product innovation has a positive and significant on marketing performance. It can be concluded that $\mathrm{H}_{2}$ and $\mathrm{H}_{3}$ are accepted. The indirect test results show that the mediation effect product innovation on the relationship between adaptive capability and marketing performance is having a significant impact. So, it can be stated that $\mathrm{H}_{4}$ is supported.

\section{Discussion}

The study aimed to explore the relationship between adaptive capability and marketing performance in SME with product innovation as a mediating variable. The results from PLS-SEM revealed that product innovation positively related to marketing performance. In addition, it is also known that adaptive marketing has a significant effect on product innovation, but surprisingly, its links with marekting performance were not significant. The study was carried out in a developing country's SMEs. The adaptive capability does not affect marketing performance, this is caused by the mismatch of the adaptation process that is carried out with the demands of changing business environment. Bourgeois (1980) revealed that the relationship between adaptability and company performance is non-linear. Where it is stated that the level of excessive adaptability or over adaptability will make the company's performance counterproductive, and there will be a decrease in the company's performance. Furthermore, this study revealed that adaptive capability has a significant effect on product innovation. The adaptation process encourages SMEs to continue to adjust their products to the market by continuing to innovate. Adaptability refers to the ability to show the response and change needed for an existing or potential situation. Hence, it is necessary to coordinate, organize and allocate resources, to meet the changes requested by customers or suppliers, or create the company's own environment. Akgun, Keskin, and Byrne (2012) adaptability is the ability to identify and take advantage of the emerging market and technological opportunities. Companies form their adaptive strategies according to their perception of the environment. Adaptive abilities influence the process of reshaping resources and coordinating processes in time to develop better and successful products. 
Consistent with previous research (Rosli, Sidek, 2013; Lin et al., 2013) in this research, product innovation influences marketing performance, which is because product innovation can produce product uniqueness and novelty that tends to be more accepted by the market and able to expand the market. Companies with strong product innovation have good performance, where product innovation will open up greater opportunities to differentiate existing products from competitors. Besides, product innovation mediates perfectly the relationship between adaptive capability with marketing performance. Market adaptation will have a significant impact on marketing performance if mediated by innovation, which means that marketing performance is highly dependent on the level of innovation of the company and also the level of market adaptation that affects innovation. SME marketing performance is highly dependent on the level of innovation of the company and also the level of market adaptation that affects innovation.

\section{References}

Aldrich, H. (1979). Organizational change; Organizational sociology; Social sciences Research. Prentice-Hall.

Ali, Z., Sun, H., \& Ali, M. (2017). The Impact Of Managerial and Adaptive Capabilities to Stimulate Organizational innovation in SMEs: a complementary PLS-SEM Approach. Sustainability, 9(12), 2157.

Altuntaş, G., Semerciöz, F., \& Eregez, H. (2013). Linking strategic and market orientations to organizational performance: the role of innovation in private healthcare organizations. Procedia-Social and Behavioral Sciences, 99, 413-419.

Bain, J.S. (1956). Barriers to New Competition, Harvard University Press, Cambridge, MA.

Beal, R. M. (2000). Competing Effectively: Environmental scanning, competitive strategy, and organizational performance in small manufacturing firms. Journal of small business management, 38(1), 27.

Bourgeois III, L. J. (1980). Strategy and Environment: A conceptual integration. Academy of Management Review, 5(1), 2539.

Bruce, H \& Montana, P. J. C.,. (2000). Administracion/Patrick J. Montana, Bruce H. Charnov; Tr. Mario Zamora Mercado (No. HD31. M618 2006.).

Chakravarthy, B. S. (1982). Adaptation: A promising metaphor for strategic management. Academy of Management Review, 7(1), 35-44.

Covin, J. G., \& Slevin, D. P. (1989). Strategic management of small firms in hostile and Benign environments. Strategic management journal, 10(1), 75-87.

Dirgiatmo, Y., Abdullah, Z., \& Ali, R. H. R. M. (2019). The role of entrepreneurial orientation in intervening the relationship between social media usage and performance enhancement of exporter SMEs in Indonesia. International Journal of Trade and Global Markets, 12(2), 97-129.

Geehuizen, M.V. \& Indarti, N. (2005). Knowledge as a Critical Resource in Innovation among Small Furniture Companies in Indonesia: an Exploration. Gadjah Mada International Journal of Business, 7(3), 371-390.

Grinstein, A. (2008). The Relationships Between Market Orientation and Alternative Strategic Orientations: A metaanalysis. European Journal of Marketing, 42(1/2), 115-134.

Hair, J. F. Hult, G.T., Ringle, C., \& Sarstedt, M. (2014). A Primer on Partial Least Squares Structural Equation Modeling (PLS-SEM): Sage Publications.

Hambrick, D.C. (1983). Some Test of the Effectiveness and Functional Attributes of Miles.

Han, J.K., Kim, N. \& Sriyastaya, R.K. (1998). Market Orientation and Organizational Performancfe: Is Innovation a Missing Link?. Journal of Marketing, 62, 30-45.

Hansen, S. \& Wernerfelt, B. (1989). Determinants of Firm Performance: The Relative Importance of Economic and Organizational Factors. Strategic Management Journal, 10(5), 399-411.

Hitt, M.A., Ireland, D., Camp, S.M. \& Sexton, D.L. (2001). Strategic Entrepreneurship: Entrepreneurialstrategis For Wealth Creation. Strategic Management Journal, 22(6-7), 479-491.

Hult, G.T.M. \& Ketchen, D.J. (2001). Does Market Orientation Matter? A test of the relationship between positional advantage and performance. Strategic Management Journal, 22(9), 899-906.

Hurley, R.F. \& Hult, T.M. (1999). Innovation, market orientation an organizational learning: An integration and empirical examination. Journal of Marketing, 62, 42-54.

Ismail, T. (2015). Cultural control, creativity, social capital and organizational performance: Empirical study of Small to Medium Sized Enterprises (SME) In Indonesia. International Journal of Entrepreneurship, 19, 60-73.

Jajja, M. S. S., Kannan, V. R., Brah, S. A., \& Hassan, S. Z. (2017). Linkages between firm innovation strategy, suppliers, product innovation, and business performance: insights from resource dependence theory. International Journal of Operations \& Production Management, 37(8), 1054-1075.

Keats, B.W., \& Hitt, M.A. (1988). A Causal Model of Linkage Among Environment Dimensions, Macro Organizational Characteristic and Performance. Academy of Management Journal, 31, 570-598

Lin, R. J., Tan, K. H., \& Geng, Y. (2013). Market demand, green product innovation, and firm performance: evidence from Vietnam motorcycle industry. Journal of Cleaner Production, 40, 101-107.

Lu, Y., Zhou, L., Bruton, G., \& Li, W. (2010). Capabilities as a mediator linking resources and the international performance of entrepreneurial firms in an emerging economy. Journal of International Business Studies, 41, 419-436

Nuryakin, N., \& Ardyan, E. (2018). The Important Role of Customer Information Quality on Salesperson Performance. In Proceedings of the 1st International Conference on Science and Technology for an Internet of Things. European Alliance for Innovation (EAI). 
Oktemgil, M., \& Greenley, G. (1997). Consequences of high and low adaptive capability in UK companies. European Journal of Marketing, 31(7), 445-466.

Pardi, Suharyono, Imam, S., \& Zainul, A. (2014). The effect of market orientation and entrepreneurial orientation toward learning orientation, innovation, competitive advantages and marketing performance. European Journal of Business and Management, 6(21), 69-80.

Prajogo, D. I. (2016). The strategic fit between innovation strategies and business environment in delivering business performance. International Journal of Production Economics, 171, 241-249.

Rosli, M. M., \& Sidek, S. (2013). The Impact of Innovation on the Performance of Small and Medium Manufacturing Enterprises: Evidence from Malaysia. Journal of Innovation Management in Small \& Medium Enterprises, $2013,1$.

Talaja, A. (2013). Adaptive capabilities, competitive advantage and company's performance. Ekonomski Pregled, 64, 49-63.

Tuominen, M., Rajala, A., \& Möller, K. (2004). Market-driving versus market-driven: Divergent roles of market orientation in business relationships. Industrial Marketing Management, 33(3), 207-217.

Zahra, S. A. (1996). Technology strategy and financial performance: Examining the moderating role of the firm's competitive environment. Journal of Business Venturing, 11(3), 189-219.

Zhu, W., Su, S., \& Shou, Z. (2017). Social ties and firm performance: The mediating effect of adaptive capability and supplier opportunism. Journal of Business Research, 78, 226-232.

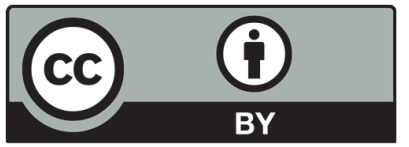

(C) 2020 by the authors; licensee Growing Science, Canada. This is an open access article distributed under the terms and conditions of the Creative Commons Attribution (CC-BY) license (http://creativecommons.org/licenses/by/4.0/). 